\title{
HOBBES: A VOLUNTARIST ABOUT THE PERMISSIBILITY OF STATE ENFORCEMENT?
}

\author{
HOBBES: UM VOLUNTARISTA ACERCA DA PERMISSIBILIDADE \\ DA AUTORIDADE ESTATAL?
}

\author{
Daniel Guillery* \\ d.guillery.12@ucl.ac.uk
}

\begin{abstract}
I take up the question of what argument, if any, Hobbes has for state legitimacy, which term I stipulatively use to mean the general, exclusive permission to enforce compliance with their directives or laws that states are standardly taken to have. I will argue that, contrary to what one might imagine, the ground of state legitimacy for Hobbes is not to be found in the social contract or the authorisation of the state's subjects, but rather in the sovereign's simply not being subject to the kind of laws that rule out enforcement for subjects. The sovereign's right to enforce is based in exactly the same sort of right that all have when not subject to any higher sovereign power. Though this must be nuanced (the sovereign does not literally retain its right to all things from the state of nature, since no sovereign existed in the state of nature), the permissibility of enforcement for Hobbes is to be found simply in the lack of anything that might make it impermissible.
\end{abstract}

Keywords: Hobbes, legitimacy, voluntarism, enforcement, political obligation.

Sumário. Trato a questão de saber que argumento tem Hobbes a favor da legitimidade do Estado, um termo que uso para designar a permissão geral e exclusiva para impor a obediência com as directivas e leis que os Estados tipicamente têm. Irei argumentar que, ao contrário do que possamos imaginar, o fundamento da legitimidade do Estado para Hobbes não se encontra no contrato social ou na autorização dos súbditos do Estado, mas antes no facto de o soberano não estar sujeito ao tipo de leis que retiram aos súbditos a autoridade de impor. $O$ direito do soberano impor a lei baseia-se exactamente no mesmo tipo de direito que todos têm quando não estão submetidos a um poder soberano superior. Embora isto deva ser qualificado (o soberano não mantém literalmente o seu direito natural a todas as coisas, uma vez que não existia qualquer soberano no estado de natureza), a permissibilidade da autoridade encontra-se, em Hobbes, simplesmente na falta de algo que poderia tornar essa autoridade inaceitável.

Palavras-chave: Hobbes, legitimidade, voluntarismo, imposição, obrigação política.

\footnotetext{
* PhD student in philosophy at University College London.
} 


\section{o. Introduction}

There are at least three important dimensions of moral evaluation of states. I will call these obligating power, legitimacy and justification. By the first two terms I mean the following:

Obligating power. A state $\mathrm{X}$ has obligating power over an individual $\mathrm{Y}$ in some domain $\mathrm{D}$ if and only if X's commands/directives in $\mathrm{D}$ create duties/obligations/pre-emptive reasons for $\mathrm{Y}$ to act as commanded/directed, independent of their content (within some limits). ${ }^{1}$

Legitimacy. A state $\mathrm{X}$ is legitimate with respect to individual $\mathrm{Y}$ if and only if $\mathrm{X}$ has a general and exclusive moral permission to enforce Y's compliance with its commands/directives/laws independent of their content (within some limits). ${ }^{2}$

I mean these definitions to be purely stipulative. ${ }^{3}$ Obligating power is just the flipside of what is often called 'political obligation': if subject $\mathrm{Y}$ has a political

\footnotetext{
${ }^{1}$ On pre-emptive reasons see Raz (1988) ch. 3 and (1979) 18; a pre-emptive reason to $\varphi$ is a reason that pre-empts, excludes from consideration or replaces certain other reasons for or against $\varphi$-ing. (My label might be slightly misleading since one might have a pre-emptive reason to $\varphi$ without having an obligation to $\varphi$ ). X's having obligating power over Y involves (in Hohfeldian terms) it having a moral power to change Y's normative situation, but it is consistent with X's also having a claim right to Y's obedience or not. For discussion of this distinction see Copp (1999) 10-21. For X's commands/directives to create a duty (etc.) need not require that X's command be in any sense the ultimate source of the duty. For instance, if $\mathrm{Y}$ promises to obey whatever commands $\mathrm{X}$ makes, and then on some subsequent occasion $\mathrm{X}$ commands $\mathrm{Y}$ to $\phi$, Y now has a duty to $\phi$ that she did not have before. $\mathrm{X}$ has created this duty, even though, in some sense, its ultimate source is Y's promise, not X's command; Y only has the duty to $\phi$ as a part of the more general duty to do whatever X commands.
}

${ }^{2}$ What is meant here by 'content-independence' is slightly more straightforward for obligating power than for legitimacy. In the former case, X's having content-independent obligating power over Y can be understood as it being the case that, for any $\phi$, that $X$ commanded it is sufficient for, and the reason for, Y's being required to $\phi$ so long as some conditions are met (and these conditions give the limits mentioned in the definition above). For legitimacy, content-independence will have to be cashed out as something like its being the case that $\mathrm{X}$ gets to decide what commands it enforces compliance with, that is, what it is permissible for $\mathrm{X}$ to enforce is not wholly determined by some other criterion (other than X's decision), such as the independent requirements of morality.

${ }^{3}$ The term 'legitimacy' is a highly contested term whose use is much debated by philosophers. I do not intend my definition as an analysis of the term, nor as a contribution to the debate about how it should be used. I use the term because the property I mean to pick out is one that has often been closely associated with that term and I think some 
obligation (a content-independent obligation to obey the commands of her state), the state has obligating power over Y. To have obligating power over Y is just for it to be the case that one's making a command or directive creates a duty/obligation/pre-emptive reason for Y to act accordingly.

The third dimension, which I am referring to as the question of 'justification' asks whether the existence of a state is, in some sense a good thing or morally acceptable. (This is, I think, what A. John Simmons has in mind when he famously distinguishes justification from legitimacy, though he uses the latter term differently from me). 4 The word 'justification' is often used in connection with actions, as when we ask whether someone is justified in doing something. This is not the way I mean to use the term here. Existing is not an action, and entities cannot be justified in existing in this sense. It may be that when people talk about justifying the state, or showing that a state is justified, they mean to refer elliptically to showing that a state is justified in doing certain things (perhaps those things essential to or characteristic of states). Since enforcement is often taken to be essential to states, showing that a state is justified in doing things essential to its statehood may end up amounting to establishing what I above called its legitimacy (which I will turn to below). But I think that talk of states being justified may also refer to something different, having to do with the moral status of the state's existence. When I refer to a state's justification or being justified, I refer exclusively to this latter thing. There are still several different things that might be meant here, but I think there is a family of questions having to do with the quality of the state and whether it is something whose existence we should accept or be glad for: it could be that it is justified if and only if it is better that it exist than not, or if it meets some evaluative threshold, or something else along these lines. This family of questions is quite separate from what I have called obligating power and legitimacy. 5

\footnotetext{
writers have used the term as a name for this property, but if the use of the contested term is confusing, then any other name can be substituted.

${ }^{4}$ Simmons (2001) 122-57

${ }^{5}$ Simmons also talks about justifying the state by 'showing that some realisable type of state is on balance morally permissible' (2001, 125-6). Institutions are not really candidates for permissibility; it is actions that are either permissible or not, but a state's being justified could be understood as its being morally permissible to create that state
} 
It should be clear that these three dimensions of evaluation are at least distinct conceptually. Hobbes might be read with an eye to any of them. The easiest to discern is justification and Hobbes also takes himself to have an argument for obligating power, but here I want to consider what materials there are in Hobbes for a defence of legitimacy.

Hobbes's well-known state-of-nature argument is most obviously associated with justification. The familiar argument, very roughly, is that human nature is such that 'during the time men live without a common power to keep them all in awe, they are in that condition which is called war'. ${ }^{6}$ Thus, life without a state is awful and so 'it is a precept, or general rule of reason, that every man, ought to endeavour peace, as far as he has hope of obtaining it'. 7 However, the only way to ensure that this is acted on is to have a state (indeed, an absolute state). It seems quite clear how this can give us a justification of the state, what David Schmidtz calls a 'teleological justification'. ${ }^{8}$ A state is teleologically justified by its fulfilling certain goals. Here, the state is justified by its being necessary for the achievement of peace. A teleological justification of an institution gives us reason to think of it as good in some way, and it may become a premise in an argument that we ought to create (or promote or preserve) that institution. Hobbes also takes himself to have given an argument for obligating power. I will

\footnotetext{
or impermissible to destroy it or something similar. Indeed, Hobbes's justification argument might well be interpreted as an argument to the conclusion that it is permissible to create the state. (It is plausibly interpreted as an argument that it is permissible to create any state because any state is better than the state of nature). Hampton $(1986,269)$ argues that social contract arguments (including Hobbes's) are supposed to show just such a thing. I take it, though, that if this is Hobbes's conclusion, it is supposed to follow from an intermediate conclusion more like how I have characterised a state's being justified above. If Hobbes thinks that it is permissible to create a state this is presumably because of its being good in some way, its possessing certain virtues (at least comparatively with the state of nature). I do not think that a conclusion about the permissibility of creating a state follows directly from its meeting some evaluative threshold, its being better that it exists than not, or its being better than the state of nature (as I have argued elsewhere). Thus, I will treat Hobbes's justification argument as just an argument that the state is good in some way rather than an argument for the permissibility of creation.
}

${ }^{6}$ Hobbes (1996) 84 (13:8:62). I make reference to the Oxford edition that I am using, but I also provide in parentheses references in the following form: (chapter: paragraph: page number of the 1651 edition).

${ }^{7}$ Ibid. 87 (14:4:64)

${ }^{8}$ Schmidtz (1990) 102 
not attempt to identify what exactly it is, but it must be something additional to the argument for justification. If we take seriously what Jonathan Wolff calls Hobbes's 'self-assumption principle', 9 the principle that there is 'no obligation on any man which ariseth not from some act of his own', a teleological justification of the state is not sufficient to establish an obligation to obey on the part of its citizens. ${ }^{10}$ This is the basis of Wolff's objection to a hypothetical contract interpretation of Hobbes: 'if I am to have an obligation to obey the sovereign', given the self-assumption principle, '[i]t cannot be a consequence of something I merely would have done'. ${ }^{11}$ More generally, if the self-assumption principle holds, obligation to obey will not follow directly from a state's being justified, its possessing certain virtues. ${ }^{12}$

Legitimacy is (at least conceptually) independent of both. That one has an obligation (or duty or pre-emptive reason) to $\phi$ does not immediately entail that anyone is permitted to enforce your $\phi$-ing. Certain moral requirements may be such that, in virtue of being under such a requirement, one is liable to be permissibly coerced by certain others, but this is not a general feature of moral requirement. For instance, one may have an obligation to keep a promise to a friend consistently with nobody else being permitted to enforce your keeping the promise. In particular, that one has an obligation to obey some institution does not, without additional premises, entail that that institution is permitted to enforce your compliance. ${ }^{13}$ Additionally, legitimacy does not immediately follow

\footnotetext{
${ }^{9}$ Wolff (1994) 271

${ }^{10}$ Hobbes (1996) $144(21: 10: 111)$

${ }^{11}$ Wolff (1994) 274

${ }^{12}$ Simmons, in the titular essay of his (2001), argues that what he calls 'legitimacy' (something like the conjunction of what I call 'legitimacy' and obligation, with the key part being obligation) does not follow from justification. Hume perhaps does argue for obligation from justification (see Hume (1994), e.g. essays 4 and 23), but he does not hold the self-assumption principle, and he will need additional premises to get from justification to obligation.

${ }^{13}$ Both Green (2004) and Wellman (1996), who note that the question of obligating power is separate from the question of legitimacy, seem to think that political obligation does entail the legitimacy of state coercion; that is, they think that it is not possible for a state to have obligating power but no permission to enforce. Neither, though, offers any argument for this claim and there seems to be no reason to think that it must be permissible for someone to enforce a set of rules in order for one to have an obligation to obey those rules.
} 
from a state's being justified in the above sort of sense (roughly, its existence being a good thing) that it is permitted to enforce its directives over its subjects. A state's quality and what it is permitted to do are two separate things. Thus, we cannot expect Hobbes's argument for legitimacy, if he has one, to be just identical to his arguments for either justification or obligation. What, then, can we find in Hobbes?

In this paper, I address this question. I will begin by asking what argument Hobbes has for the legitimacy of states actually formed by the sort of contract he describes, and then I will ask how this transfers to states not formed in this way. I first consider what might seem to be a natural, voluntarist interpretation of his argument for legitimacy, which bases it in the voluntary authorisation of the covenanters. However, I argue, this cannot be Hobbes's argument for legitimacy. I then offer an alternative interpretation, according to which Hobbes has, and needs, no special argument for state legitimacy, since there is simply nothing that might make state enforcement impermissible.

\section{Actual contract}

Let us begin by considering Hobbes's account as describing an actual contract. One way of interpreting Hobbes's argument from the state of nature is as giving a historical account of how states were formed. If Hobbes gives an account of how states acquire legitimacy when formed by actual contract, then this will apply to actual states insofar as the historical picture is an accurate description of those states. However, if, as seems more plausible, Hobbes's argument should not be given a historical interpretation, we can first see how, on Hobbes's view, states acquire legitimacy in the hypothetical scenario in which they are formed by contracting out of the state of nature, and then ask how this transfers to the question of legitimacy for actual states.

\subsection{Authorisation}

There is something in Hobbes's story of the formation of states that looks somewhat like an account of legitimacy, that is, the permissibility of state enforcement. This is his story of authorisation. Artificial persons, who represent the actions of another person or other people, may 'have their words and actions 
owned by those whom they represent'. In this case, the owner of the actions is their author, and the actions are performed by authority: 'by authority, is always understood a right of doing any act: and done by authority, done by commission, or licence from him whose right it is' ${ }^{14}$ Thus, we can see what looks like the shape of a Hobbesian argument that certain actions by certain agents are permissible: if $\mathrm{A}$ is authorised by $\mathrm{B}$ to $\phi$ and $\mathrm{B}$ has a right to $\phi$, then so does A. ${ }^{15}$ Hobbes goes on to employ this notion of authorisation in his account of the formation of a commonwealth. The latter he defines as 'one person, ${ }^{16}$ of whose acts a great multitude, by mutual covenants one with another, have made themselves every one the author, to the end he may use the strength and means of them all, as he shall think expedient, for their peace and common defence'. ${ }^{17}$ The covenant is made 'in such manner, as if every man should say to every man, I authorize and give up my right of governing myself, to this man, or to this assembly of men, on this condition, that thou give up thy right to him, and authorize all his actions in like manner' ${ }^{18}$

Thus, it seems that Hobbes takes the state in his state of nature contract story to be authorised by its subjects and perhaps this is his view about how it comes to be permissible for the state to enforce its directives on its subjects. Enforcement is permissible because the state's actions, including its coercing its citizens, are owned by all of its subjects. Indeed, Hobbes argues that the sovereign's actions, whatever they may be, cannot constitute injury or injustice to its subjects:

For he that doth anything by authority from another, doth therein no injury to him by whose authority he acteth: but by this institution of a commonwealth, every particular man is author of all the sovereign doth: and consequently he that

\footnotetext{
${ }^{14}$ Hobbes (1996) 107 (16:4:81)

${ }^{15}$ By 'right' here I mean a liberty right (in the Hohfeldian sense) or a moral permission. It seems that this is also how Hobbes uses the word 'right': see Hampton (1986) 51.

${ }^{16}$ An artificial person may be constituted by a multitude of natural persons.

${ }^{17}$ Ibid. $114(17: 13: 88)$

${ }^{18}$ Ibid. $114(17: 13: 87)$
} 
complaineth of injury from his sovereign, complaineth of that whereof he himself is author; and therefore ought not to accuse any man but himself; no nor himself of injury; because to do injury to one's self, is impossible. ${ }^{19}$

Anything the state may do to its citizens is permissible, it might seem, because its actions are their actions. (At least this will be so if we take the authorisation of the state by its subjects in the Hobbesian contract to be complete, rather than an authorisation to perform certain actions only). Thus, we might think that there is an authorisation argument for legitimacy in a historical interpretation of Hobbes that goes something like this:

1. Nothing done to oneself can be impermissible. ${ }^{20}$

2. In the formation of the state by social contract, its subjects authorise it to enforce its directives on them.

3. If A authorises B to do X, B's future actions of X-ing become owned by A, that is, they become A's actions.

4. Therefore, (from 2 and 3), when a state formed by social contract enforces its directives on its subjects, they enforce these directives on themselves.

5. Therefore, (from 1 and 4), it cannot be impermissible for a state formed by social contract to enforce its directives on its subjects.

6. Therefore, a state formed by social contract has a general moral permission to enforce its directives on its subjects.

This, then, is an argument for legitimacy given an actual contract that stands independently of the argument for justification (which is the argument that it is rational to authorise the state).

In order to see if this is indeed Hobbes's argument for legitimacy within an actual contract, we should consider in more detail what exactly he takes to be involved in authorisation. Hobbes is not too clear on this point, but it seems that,

\footnotetext{
${ }^{19}$ Ibid. $117-8(18: 6: 90)$

${ }^{20}$ This is one way of reading Hobbes's claim that 'to do injury to one's self, is impossible'. It is to read 'injury' as 'impermissible treatment'. If we are to read the paragraph quoted above as Hobbes's argument for legitimacy, we will need to interpret 'injury' in this way.
} 
on the most plausible interpretation, authorisation will be some sort of giving up of right, a transfer or surrender of right. Since all have a natural right of selfpreservation, Hobbes thinks, in the state of nature, which is a condition of war, 'every man has a right to every thing'. ${ }^{21}$ In authorising the sovereign, each subject either transfers or surrenders some part or the entirety of this right to all things. This is suggested by the passage quoted above in which Hobbes comes closest to giving a definition of 'authorisation', saying that 'done by authority' means 'done by commission, or licence from him whose right it is'. ${ }^{22}$ Additionally, when Hobbes describes the covenant that creates the commonwealth, he describes it as a covenant to authorise the sovereign and he is quite clear that this covenant is one in which the covenanters give up their right to all things, or their right of governing themselves. ${ }^{23}$ However, which of these two things it is (transfer or surrender) is a point of dispute in the literature.

David Gauthier claims that 'authorisation must involve some translation of right'. He and Gregory Kavka understand authorisation along the lines of a principal-agent model where the principal temporarily grants or loans the agent some power or right she has. ${ }^{24}$ On this interpretation, authorisation involves A's bestowing a right on $\mathrm{B}$, a right that A retains. A gives $\mathrm{B}$ the right to represent $\mathrm{A}$ by granting B the use of A's right: 'authorisation (...) enables you to act in my place, and so with my right'.25 Since B, being authorised by A, is acting as A's representative, that is, with A's right, A owns B's actions in the normal, modern sense. B's actions, because done with A's right, are (as if) A's actions. The same obligations, responsibilities, rights, commitments that A would incur by $\phi$-ing herself are incurred when B $\phi s$ under A's authority. On this interpretation, the authorisation of the sovereign is seen as an agreement with some normative force (the agreement alters the normative landscape, by transferring rights from one

\footnotetext{
${ }^{21}$ Ibid. $87(14: 4: 64)$

${ }^{22}$ Ibid. 107 (16:4:81)

${ }^{23}$ See pg. 114 (17:13:87-8) and pg. 87 (14:5-6:64-5)

${ }^{24}$ Gauthier (1969) 124; Kavka (1986) 389-90.

${ }^{25}$ Gauthier (1969) 124
} 
person to another). (Hampton, by contrast, sees the authorisation of the sovereign to be a purely behavioural abandonment of right, constituted by the subjects' coming to obey the sovereign.) Such an understanding of authorisation lends itself well to the form of argument above. There is a sense in which, when B's $\phi$-ing is authorised by A, A owns B's $\phi$-ing and is responsible for it. It might be thought that whatever permissibility facts apply to actions performed by an agent also apply to actions that agent is responsible for. If this is the case, it becomes possible to make something like the argument given above.

However, Jean Hampton disputes this interpretation, claiming instead that authorisation involves a renunciation or surrender of right. ${ }^{26}$ She argues that such a 'loan' of right could not be the basis for Hobbes's absolutist theory and points to passages in which Hobbes describes the covenant as involving 'laying down' or 'divesting oneself' of rights. ${ }^{27}$ Understanding authorisation as Hampton does gives a clear picture of how authorisation creates the sovereign. By abdicating their right to all things, the covenanters cease (at least given certain conditions) to pursue whatever means they see to be most appropriate for their own protection and instead obey the commands of the sovereign. In Hampton's view, authorisation of the sovereign just is constituted by one's coming to obey the sovereign's punishment commands. ${ }^{28}$ The sovereign is created as it gains the ability to enforce its commands thanks to the generalised obedience resulting from the covenanters' abdication of their right to all things.

If we accept a Hampton-style interpretation of authorisation, the question arises what authorisation has to do with ownership; in other words, what grounds

\footnotetext{
${ }^{26}$ Hampton (1986) ch. 5. Tom Sorell (1991) similarly interprets the laying down of right as involving simply giving 'way to another in his pursuit or enjoyment of a thing' (112). He makes a different distinction between transfer and renunciation to the one made here, where the former involves giving way to only one particular person, while the latter involves giving way to anyone. In either case, though, what he takes to happen is a surrender in the sense under discussion here, not a temporary loan.

${ }^{27}$ Hobbes (1996) 114 (17:13:87-8) and 87 (14:5-6:64-5)

${ }^{28}$ She says it involves '1) participating with the other inhabitants of the state of nature in a process in which one of them is selected as sovereign ... and 2) obeying the punishment commands a) of only this individual b) to refrain from interfering in the punishment of another and c) to actively assist in the punishment of another, insofar as these commands are (or have been made by the sovereign to be) individually rational' (Hampton (1986) 186).
} 
are there for asserting premise 3 of the above argument if authorisation is just surrender of right? How does one come to own the actions of another by simply surrendering one's right to all things to them? Hampton's answer is that in $17^{\text {th }}$ century English, the words 'authorise' and 'own' could have senses slightly different from their ordinary modern senses. She points out that 'to authorise' could mean 'to set up as authoritative; to acknowledge as possessing final decisiveness ... to give final approval to; to sanction, approve, countenance', while 'to own' could mean 'to acknowledge as having supremacy, authority or power over one; to profess, or yield, obedience or submission to'. ${ }^{29}$ The former is a sense still possessed by the term 'to authorise', but the latter is obsolete. Thus, the subjects do not own the actions of the sovereign in the usual sense; rather, they acknowledge its actions as having supremacy, or something along these lines. How do these senses of 'authorise' and 'own' work with the idea that the covenanters authorise the sovereign by surrendering their right to all things? Perhaps the thought is that by surrendering their right to all things the covenanters set up the sovereign as authoritative; the surrender expresses final approval or something similar.

Can we make an argument like the above given such an interpretation? Surrender of right as simple factual obedience of commands on its own will not get us such an argument. That is, it will not get us such an argument unless it is thought that this obedience of commands constitutes in some way something like an acknowledgement of the supremacy or authority of the actions of the commander. Thus, the expression of approval or acknowledgement of authority or some such similar thing that Hampton takes Hobbes to be referring to is essential These may be constituted by the obedience, but if they are, it is in its role as an expression of approval or acknowledgement of authority that the obedience will be relevant to the argument. However, even when we add these understandings of 'authorise' and 'own' to de facto surrender of right, we still cannot quite make the argument as presented above. Once we understand 'own' as Hampton suggests Hobbes does, we can no longer make the equivalence between A's owning B's actions and B's actions being A's actions. That I

\footnotetext{
${ }^{29}$ Ibid. 126-7. She cites the Oxford English Dictionary for the senses of these words.
} 
acknowledge your actions 'as having supremacy, authority or power over' me does not make your actions my actions. The best version of the above argument we can make when we understand 'authorise' and 'own' as Hampton does is something like the following:

1. If A expresses approval of/acknowledges as permissible/engages to support... B's doing $\phi$ to A, it is permissible for B to do $\phi$ to A.30

2. In the formation of the state by social contract, its subjects authorise it to enforce its directives on them.

3. If $\mathrm{A}$ authorises $\mathrm{B}$ to do $\mathrm{X}, \mathrm{A}$ expresses approval of/acknowledges as permissible/engages to support B's future actions of X-ing.

4. Therefore, (from 2 and 3), when a state formed by social contract enforces its directives on its subjects, its doing so is approved of/acknowledged as permissible/supported by the subjects.

5. Therefore, (from 1 and 4), it is permissible for a state formed by social contract to enforce its directives on its subjects.

The problem with this version of the argument is that it depends on the very questionable new version of premise 1 . While the original version of premise 1 ('nothing done to oneself can be impermissible') may be disputable, it has at least prima facie plausibility. This one seems to lack even this: it does not seem plausible to think that people are always infallible about how it is permissible to act towards them. ${ }^{31} \mathrm{I}$ cannot, though, see any better way to construct an argument for legitimacy from the chapter 18 passage reading 'own' as Hampton does. This need not show that Hampton is wrong to interpret Hobbes's use of 'authorise' and 'own' as she does. If she is right about the meaning of 'own', we can alternatively read the passage as not being about permissibility. (This, I think, as will become clear below, is in fact the correct way to read this passage).

\footnotetext{
${ }^{30}$ The OED definition Hampton cites does not include acknowledgement as permissible or engagement to support, but these seem in the spirit of it and might do better for getting to legitimacy.

${ }^{31}$ Cases of adaptive preferences seem to be clear cases where victims of impermissible treatment wrongly see that treatment as permissible.
} 
In any case, though, whichever of these is the correct interpretation of Hobbes's understanding of authorisation, Hobbes cannot hold that the legitimacy of the sovereign is derived from authorisation (and so the passage from chapter 18 quoted above cannot be Hobbes's argument for legitimacy). ${ }^{2}$ Hobbes thinks that, since the purpose of entering into a covenant is to achieve some good for oneself, there are certain rights that are inalienable by covenant.33 Thus, 'the promise of not resisting force, in no covenant transferreth any right; nor is obliging'.34 For this reason Hobbes says that 'no man is supposed bound by covenant, not to resist violence; and consequently it cannot be intended, that he gave any right to another to lay violent hands upon his person'; and then, it is manifest therefore that the right which the commonwealth (that is, he, or they that represent it) hath to punish, is not grounded on any concession, or gift of the subjects'.35 This seems to be a fairly clear statement that Hobbes does not take any version of the above argument to be the source of the state's liberty right/permission to enforce. The above argument takes the source of the permission to be the subjects' individual voluntary authorisation of the sovereign through covenant (whether through surrender or transfer of right), but Hobbes here appears to be denying that such a thing could ground any permission to punish, which is an essential part of the permission to enforce. It is not possible, on Hobbes's view, to give up the right to self-defence to the benefit of another. As Hobbes recognises, the right to punish will not amount to much without the right to use violence to punish. Similarly, the right to enforce will not amount to much

\footnotetext{
${ }^{32}$ I do not think it is necessary for me to decide between these two interpretations; the account I will give below is consistent with both. For what it is worth, though, I think that there is probably an element of both in Hobbes. I think without Hampton's behavioural surrender of rights, the sovereign would not have the ability to enforce that makes it what it is. And, I think, either in surrendering the right to all things, or as well, the covenanters authorise the sovereign. That is, they take ownership of the actions of the sovereign. Each subject permits the sovereign to represent her, to act in her name. I don't think this should be understood as a transfer of the right to all things, but as an authorisation to decide what $I$ do. The sovereign doesn't gain a permission to do any acts that it wasn't permitted to do before, but it can now (it has the ability or power to), by acting, determine what $I$, as a covenanter, do, because its actions represent me. It gains 'the right to present the person of them all' (115 (18:1:88)).

${ }^{33}$ Ibid. 88-9 (14:8:65-6)

${ }^{34}$ Ibid. 93 (14:29:70)

${ }^{35}$ Ibid. 205-6 (28:2:161)
} 
without the right to punish. Thus, Hobbes appears to be telling us explicitly that the above is not his argument for legitimacy. Furthermore, even if these explicit statements could be explained away somehow, as will become clear below, it would not make sense for Hobbes to attempt to derive the state's legitimacy from its authorisation by its subjects. Though he seems to be a voluntarist about obligation, he is not a voluntarist about the permissibility of enforcement.

\subsection{State enforcement rights by default}

If, then, what looked like an argument for legitimacy from authorisation (at 18:6) was not in fact that, are we to conclude that Hobbes does not think states have a moral permission to enforce their commands, or that there is some other way in which the creation of the sovereign bestows upon it a permission to enforce its commands on its subjects? In fact, we should conclude neither of these things. Hobbes does not need any special argument to establish the state's moral permission to enforce. There is nothing at all special for him about this permission.

In the state of nature Hobbes thinks there are no moral constraints on what it is permissible for people to do to each other. ${ }^{36}$ The right of nature is the right to all things. It is permissible to pursue one's own interest through whatever means of violence or coercion are conducive to it.37 When inhabitants of the state

\footnotetext{
${ }^{36}$ Ibid. 85 (13:13:63)

${ }^{37}$ Hobbes appears to be entirely sceptical about the existence of state-independent and subject-independent moral facts (at least if moral facts are to be understood as categorical imperatives). Some have denied this but I think it is hard to see Hobbes in any other way. He seems to think that whatever moral facts exist are dependent on an individual's desires: 'whatsoever is the object of any man's appetite or desire; that is it, which he for his part calleth good: and the object of his hate, and aversion, evil' (Hobbes (1996) 35 (6:7:24)). See, for instance, Hampton (1986) and Tuck (1996) for different interpretations of Hobbes's moral views in line with this. Hampton's interpretation, which is quite appealing, would have the consequence that there are state-independent moral facts in Hobbes's sense, but for Hobbes on Hampton's view moral facts are just hypothetical imperatives, instrumental requirements imposed by our own selfinterest. Most importantly, though, however we understand Hobbes's moral views, it seems fairly clear that if there are any moral requirements, the only ones that apply in the absence of a common coercive power are the requirements to seek peace and to be prepared to covenant into a state (his first and second laws of nature). The laws of nature, Hobbes thinks, apply to everyone and are binding. (On Hampton's view, this is because the desire they are hypothetical on is a universal desire, the desire of self-preservation). If Hobbes thinks there are moral imperatives, they are presumably given by these. However, they are all (including the second) derived from the first (the requirement to seek peace) and
} 
of nature covenant together to establish a sovereign, they leave the state of nature, as there is now an effective coercive power over them that can establish effective binding rules, decide disputes and so on. In covenanting, they give up their right to all things and what they are permitted to do becomes determined by the sovereign. ${ }^{8}$ However, the sovereign does not covenant with its subjects, nor with anyone else and so retains its right of nature with respect to them (and with respect to other sovereigns). Thus, the sovereign does not come to have obligations in a commonwealth in the same way that the subjects do, since their obligations are just what the sovereign determines them to be (and the sovereign is not bound by its own laws). 39 The sovereign retains the right to all things; unlike the subjects, the sovereign never surrenders or transfers its right of nature to anybody else. This makes clear also how the sovereign gets an exclusive right to enforce (or to determine who may enforce): everybody else has given up their right to all things, and so what they are permitted to do is now determined by the laws the sovereign enforces.

It would not make sense for Hobbes to base legitimacy on authorisation, since in surrendering or transferring their right to all things the subjects do not give the sovereign any right to do anything it does not already have a right to do: it already has a right to do anything. The surrender or transfer of right is not without significance since the behavioural obedience that goes along with it is what makes the sovereign's enforcement possible and it is relevant to the subjects' obligations and attitudes. But it cannot be the basis of what the sovereign is permitted to do, since it adds nothing in this respect.40 Hobbes puts the point thus:

(excluding the second) only binding when a common power is in place. So long as there is no common power, there are no restrictions on how one individual may treat another.

${ }^{38}$ The laws of nature are derivable from reason alone (a derivation not dependent on any choices of the sovereign). However, they are only binding on action if the sovereign enforces them.

${ }^{39}$ See Hobbes (1996) $176(26: 6: 138)$

${ }^{40}$ Gauthier (1969) claims that authorisation does give the sovereign a new right, namely the right to act for another (124). However, I cannot see what this is supposed to amount to, since there is no resulting change in the extension of the sovereign's permissions: the range of actions that is permissible for the sovereign is not altered by authorisation. In particular, authorisation can make no change to the permissibility of enforcement. 
I have (...) showed formerly that before the institution of commonwealth, every man had a right to every thing, and to do whatsoever he thought necessary to his own preservation; subduing, hurting, or killing any man in order thereunto. And this is the foundation of that right of punishing which is exercised in every commonwealth. For the subjects did not give the sovereign that right; but only in laying down theirs, strengthened him to use his own, as he should think fit, for the preservation of them all: so that it was not given, but left to him, and to him only; and (excepting the limits set him by natural law) as entire, as in the condition of mere nature, and of war of every one against his neighbour. 41

Thus, the sovereign is permitted to enforce its commands because it is not in a condition in which the sort of constraints that might make it impermissible to enforce one's commands on others exist. (This must be nuanced slightly, as suggested by Hobbes's caveat 'excepting the limits set him by natural law', which I will discuss below). These latter only exist between people subject to a common coercive power and a sovereign, by definition, is subject to no such thing. ${ }^{2}$ The sovereign gains the ability to coerce you from other people's abdication of the right to all things, which amounts to a commitment to obey (or just the behavioural fact of obedience), but the abdication of right does not give the sovereign any permission right that it did not have before. In addition, the abdication of right could yet be the basis of Hobbes's argument for obligation, but not his argument for legitimacy.

If this is correct, how are we to interpret the passage from chapter 18 that suggested an authorisation-based argument for legitimacy? I think we can understand this passage if we do not interpret 'injury' as meaning simply 'impermissible harm'. It must be something that it is possible to do in the state of nature, where everything is permissible, since if injury were only possible under a sovereign, we would expect Hobbes's argument for the impossibility of injury by the sovereign to be based on the fact that the sovereign creates the conditions for the possibility of injury (echoing his argument that the law cannot be unjust). On the other hand, it cannot be simply harm, since it obviously is possible to harm oneself, contra what Hobbes says in the passage. Perhaps then it is something like 'harm at which one can rightfully feel aggrieved, or to which one can rightfully retaliate'. If we take literally Hobbes's talk of the sovereign's actions to its subjects being equivalent to actions they do to themselves, then clearly one

\footnotetext{
${ }^{41}$ Hobbes (1996) 206 (28:2:161-2)

${ }^{42}$ The requirements of justice are entirely established by the law, to which the sovereign is not subject (176 (26:4:137)).
} 
cannot feel aggrieved at what one does to oneself. If we do not take this talk literally, we can instead read the passage as claiming some sort of inconsistency in recognising or acknowledging the sovereign's actions as authoritative or having supremacy while feeling aggrieved at them. On this picture, the covenanters surrender their right to all things, expressing acknowledgement of the sovereign as being authoritative or having supremacy, in order to allow the sovereign to govern and establish order. They cannot then complain of injury by the sovereign, since it is they who empowered the sovereign and recognised (thereby creating) its authority. 43

\subsection{Problems and nuances}

One seeming problem with the way I have explicated the sovereign's right to enforce is that it may suggest a picture where the sovereign exists in the state of nature and then a group of covenanters come together and agree to obey this sovereign, who retains the right to use violence that it had all along. This is the wrong picture because Hobbes's sovereign is an artificial person, not a natural person, and it is created by the act of covenant. By covenanting to obey a sovereign the covenanters create that sovereign. So the sovereign, in fact, did not exist in the state of nature. It could not have done: what characterises the state of nature is that there is no sovereign. The language of retention may suggest a picture where the sovereign persists from the state of nature, but, so long as it is not understood in this temporal way, there is no problem for my picture. The right of nature (the right to all things) is a right possessed by all persons not living in a commonwealth (that is, under a sovereign) with civil laws forbidding and requiring certain things. For all persons not living in such a state, there are no constraints on permissible treatment of others. There is no reason why this should be true only of natural persons and not of artificial persons. In

\footnotetext{
${ }^{43}$ An alternative possibility is that Hampton is right to point to these non-standard uses of 'authorise' and 'own' but wrong to equate authorisation with surrender of right. In chapter 17 Hobbes says that it is as if the covenanters say 'I authorise and give up my right of governing myself ...' (Hobbes (1996) 114 (17:13:87), my emphasis). It could be that the authorisation is just an expression of approval or recognition of authority/supremacy and it is with this that considering oneself to be injured by one's sovereign is inconsistent, while the surrender of right is something separate. This, though, would raise the question why the authorisation, as distinct from the surrender of right, is necessary to create the sovereign, or for the purposes of the covenanters.
} 
covenanting with each other, the covenanters give up their right of nature. In doing so, they create a sovereign who does not covenant with them, who does not live under the power of a sovereign. Thus, this newly created artificial person has the same right to all things that any person has when they do not live under a commonwealth.

Now, it might be objected that the distinction Hobbes makes between punishment and hostility seems to pose a challenge for this interpretation. In chapter 28 ('Of Punishments, and Rewards'), the same chapter in which the passage quoted above occurs where Hobbes bases the right to punish on the right of nature, he clearly distinguishes between punishment and acts of hostility and sets out a number of conditions that an infliction of harm by the sovereign on a subject must fulfil in order to qualify as a punishment and not an act of hostility. For instance, he says that 'the evil inflicted by public authority, without precedent public condemnation, is not to be styled by the name of punishment; but of an hostile act'. 44 Hobbes defines punishment as 'an evil inflicted by public authority, on him that hath done, or omitted that which is judged by the same authority to be a transgression of the law; to the end that the will of men may thereby the better be disposed to obedience'.45 Punishment is done 'by public authority' and so is not possible in the state of nature; all harms inflicted in the state of nature are acts of hostility. Thus, it seems, Hobbes does not think the sovereign is in the state of nature with respect to its subjects or that its acts of enforcement just are equivalent to acts of hostility performed in the state of nature. There is a subset of harms inflicted by the sovereign that have a different status, and it is these that his account of legitimacy is primarily concerned to justify. ${ }^{46} \mathrm{I}$ think this is right, but I do not think it means that we need to reject the interpretation I have given above. It points, though, to a nuance that must be added to that interpretation.

\footnotetext{
${ }^{44}$ Hobbes (1996) 206 (28:5:162). Again, in chapter 30, Hobbes says that those who do not understand the right the sovereign has to make and enforce law 'take [punishment] but for an act of hostility; which when they think they have strength enough, they will endeavour by acts of hostility, to avoid' (223 (30:4:176)).

${ }^{45}$ Ibid. $205(28: 1: 161)$

${ }^{46}$ In the same passage quoted above in which Hobbes rules out the possibility of injury by the sovereign, he also says that 'it is true that he that have sovereign power may commit iniquity' (18:6:90, my emphasis). It is thus not the case for Hobbes that the sovereign's actions are just not open to criticism.
} 
The sovereign's right to enforce (and right to punish) are explained simply by its retaining the same right to inflict those harms involved in enforcing or punishing that it has by virtue of not being subject to a sovereign power. However, this is not just because the sovereign is in the state of nature with respect to its subjects.

When a commonwealth is instituted, all those involved are put out of the state of nature. The sovereign is thus not created in a state of nature; the moment of its creation coincides with the end of the state of nature (for the society in question). None involved are in a situation characterised by war and insecurity, but rather one characterised by law and stability. This is true for the sovereign just as much as for the subjects. The laws of nature that could not require action in the state of nature come to be binding on action since there now is a power that can ensure compliance by other parties. The laws of nature are derived purely from what is in the interests of an individual's self-preservation; they are binding on an individual because she is presumed to desire her own preservation. 47 Outside of a commonwealth, all but the first two laws of nature fail to be binding on action when one can rationally fear others' non-compliance, since complying with them will not in fact be conducive to self-preservation in such scenarios. However, it is in the interests of all for the laws of nature to be observed, and so for their observance to be enforced (because their observance is necessary for the persistence of a stable commonwealth). This is true for the sovereign as much as for the subjects: it is (just as much as for anyone else) in the interests of the sovereign for a stable commonwealth to persist; 'the good of the sovereign and people, cannot be separated'. 48

Thus, there are certain constraints on what a sovereign may or should do to its subjects and these are placed by the laws of nature. 49 The sovereign is required by rationality to enforce the laws of nature, since its own self-preservation

\footnotetext{
${ }^{47}$ Ibid. $86(14: 3: 64)$

${ }^{48}$ Ibid. 230 (30:21:182)

${ }^{49}$ See also Hobbes's distinction between good laws and just laws (230 (30:20:181-2)). All laws are just, justice is simply determined by the laws the sovereign makes. However, it is not possible for the civil laws to conflict with the laws of nature; the laws of nature must be a part of the civil laws. Purported laws which conflict with the laws of nature will not be laws (177 (26:8:138)). A sovereign may permissibly make any laws within this constraint, and so whatever they require will be just, though they may fail to be good.
} 
requires the commonwealth to persist, which requires the laws of nature to be enforced. (The sovereign is constrained by the laws of nature in a different way to the subjects: the sovereign must enforce the laws of nature; the subjects must obey them. Additionally, these requirements of right reason are not constraints in quite the same way as the laws enforced by the sovereign. Only the civil laws impose requirements of justice, since the latter depend on sovereign enforcement. The requirements of right reason could be thought of as advice rather than constraints on permissibility, or we could say that there are just two sorts of permissibility).

Much of the second part of Leviathan is taken up by claims about what sovereigns ought and ought not to do. I think this can all be understood in this way: there are constraints on what sovereigns should do, including on how they should treat their subjects, and these constraints are placed by the sovereign's need for the preservation of the commonwealth. Hobbes's distinction between punishment and hostility may be explained in these terms: acts of punishment are those that are conducive to the maintenance of a stable commonwealth; acts of hostility put the recipient outside of the protection of the sovereign and in a state of war with regard to it. The sovereign may do this to some of its subjects, but not to all, since that would amount to the dissolution of the commonwealth.

However, it is still the case that the only source of the permissibility of enforcement for the sovereign is the right of nature. When the commonwealth is instituted, certain actions become impermissible for the subjects: those ruled out by the civil laws, the laws made by the sovereign. Though it does not happen in separate temporal stages, something similar happens for the sovereign. The sovereign is created a person subject to no sovereign and so has a right to all things, but because it is not in a state of nature, there are certain limitations on this right to all things (whether they are thought of as constraints on permissibility or simply as constraints on what it is advisable to do is not important). The sovereign, however, is not subject to the civil laws, but only to the laws of nature (and certain other requirements imposed by the need to preserve the commonwealth). Everything that is not ruled out in this way remains permissible (in both senses of 'permissible'). The sovereign and the subjects alike retain intact their right of nature as far as is left open by the laws that apply. 
Unlike the subjects, though, the sovereign is only constrained by the laws of nature (and the requirement not to endanger the commonwealth). Everything else remains permissible, including the use of violence against others (except in certain special circumstances where its use threatens the commonwealth). 50 There is thus no special positive argument for the permissibility of enforcement. This is what is meant by the passage quoted above.

The way I have presented the foregoing picture takes the laws of nature to be constraints on permissibility (imposed by the requirement of rationality to do what is necessary for one's self-preservation), that is, limitations on the right of nature. If this is correct, the right of nature is not quite a right to do anything whatsoever, but a right to do anything tempered by certain requirements of right reason. I think this is the right way to understand the laws of nature, though my overall argument does not turn on it. However, the requirements that apply to inhabitants of the state of nature and to sovereigns (if we consider them to be requirements at all) are clearly of a different sort to the requirements of justice that can only bind subjects of a commonwealth through civil laws created by a sovereign.

That the laws of nature are constraints on the right to all things is suggested by the passage quoted above from chapter 28 in which Hobbes says that the right to all things is left to the sovereign entire 'excepting the limits set him by natural law' (my emphasis).51 This suggests that there are certain constraints on the sovereign's behaviour imposed by the laws of nature. These are presumably binding on the sovereign in just the same way that the laws of nature are binding on the inhabitants of the state of nature (though, of course, there it is only the first two laws that are binding). $5^{2}$ However, these constraints are not binding on

\footnotetext{
${ }^{50}$ In addition, as Sorell (1991) says, 'the sovereign's obligations to the many are no more binding than obligations between the many before there is a sovereign to over-awe them' (119). In other words, whatever constraints do exist on the sovereign's treatment of its subjects are binding only in the same way in which the laws of nature are binding on the inhabitants of the state of nature.

${ }^{51}$ Hobbes (1996) 206 (28:2:162)

52 Sorell (1991) thinks that there can even be obligations in the state of nature for Hobbes, only people can rationally hold back from making covenants or following the laws of nature for fear that others will not honour their obligations (113).
} 
the sovereign in the same way as the civil laws (including the laws of nature) are binding on the subjects. The requirement to enforce the laws of nature is binding on the sovereign simply because of its necessity for the preservation of the commonwealth. For the subjects, the threat of punishment at least has an important role to play in explaining the bindingness of the civil laws and laws of nature.53 Only the latter sort of requirements are requirements of justice. The sovereign's enforcement, when within the limits imposed by right reason, is permissible in both senses. It infringes neither requirements of justice (because the sovereign can be subject to no such requirements) nor requirements of right reason.

One might find this picture implausible because it leaves the right to all things as not really a right to all things. This element of the picture, though, is superfluous to my primary purpose. You need not accept it to accept my primary contention. All I need to say to explain the distinction between punishment and hostility consistently with my account of legitimacy in Hobbes is that the sovereign is not literally in the state of nature with respect to its subjects, but it has the same right to all things (albeit perhaps with certain limitations) that all persons have when not subject to a sovereign power. (If the laws of nature are not constraints on inhabitants of the state of nature, then there are presumably no constraints on permissibility for sovereigns and the classification of certain acts

\footnotetext{
${ }^{53}$ In justifying the secondary laws of nature Hobbes frequently appeals to the fact that behaviour of the sort demanded is required by the first law, the imperative to seek peace. This might be read as the reason that sovereigns ought in all circumstances to enforce these laws of nature, but often the language used suggests that this fact is itself the reason for following the law (e.g. he says that 'he that shall oppose himself against [the fifth law] ... is guilty of the war that thereupon is to follow'; Hobbes (1996) 101 (15:17:76)). This appears to suggest that when people are assured (by the sovereign's enforcement) that others will behave alike, the necessity of compliance with the laws of nature for the preservation of the commonwealth (which is in their interests) is itself the reason they ought to comply. On this picture, what is permissible for the subjects of a commonwealth is determined by what laws the sovereign enforces enforcement is necessary for a law to be binding, but the reason they ought to obey certain laws (the laws of nature) if enforced by the sovereign is not simply that they will be punished if they do not, but also that their compliance is necessary for the maintenance of the commonwealth, which is necessary for their self-preservation. The problem with this is that no individual's compliance is strictly necessary for the maintenance of the commonwealth. Hobbes's answer to this is his answer to 'the fool': failure to comply would make you unfit to be accepted into a civil society and so lead you to be returned to a state of war (or simply to be punished by the sovereign). Thus, the primary reason to obey, it seems, must be to avoid punishment, but it may be that there is also a secondary reason to comply with the laws of nature in particular, which is derived from the requirement to seek peace.
} 
of violence as acts of hostility has nothing to do with their permissibility. Still, the sovereign is not in the state of nature, and so acts of hostility are at least different from acts of punishment for this reason). It is the fact that enforcement is not ruled out by limitations on the sovereign's right to all things (if there are any) that explains the permission to enforce rather than any special positive argument.

\section{Hypothetical contract}

Now, thus far, we have been considering Hobbes's argument as if it is a historical argument basing the power of states (and perhaps the obligation to obey and the permission to enforce) on an actual historical contract. An alternative is to interpret Hobbes's contract as a hypothetical contract that is imagined by Hobbes in order to serve some role in argument about actual states without itself being an argument about actual states. We can see how the hypothetical contract quite straightforwardly provides a teleological justification of the state of the sort described at the beginning of this essay. We imagine how things would be in the absence of the state and conclude that it is much better with the state: the state is necessary for the fulfilment of some important goal, here the achievement of peace. 54 However, it is less immediately obvious how a description of a hypothetical contract could serve as an argument for either obligation or legitimacy. Considering legitimacy, it should be fairly obvious that the form of argument from authorisation discussed above could not hope to work if the contract is taken to be hypothetical rather than historical (and of course I have rejected it as an interpretation of Hobbes even within a hypothetical contract). If the contract is taken to be hypothetical, not actual, there is no claim that the actual citizens of actual states have authorised the state in the way that the covenanters in the hypothetical contract scenario have. That, because they have authorised the state and so own its actions, hypothetical covenanters cannot be injured by that hypothetical state is quite obviously no argument that actual citizens of actual states cannot be injured by those states, since they have not authorised their state and so cannot be assumed to own its actions.

\footnotetext{
${ }^{54}$ This may show, if successful, at least that some state is justified.
} 
We can also see that interpreting the contract as a hypothetical one makes a major difference to the argument for obligation. As has often been noticed, a hypothetical contract argument is a very different sort of animal to an actual contract argument. In the words of Ronald Dworkin, 'a hypothetical contract is not simply a pale form of an actual contract; it is no contract at all'.55 If a hypothetical contract is to be the basis for political obligation, it cannot provide the sort of voluntarist argument that an actual contract could. If the actual contract is of the right sort, those who have contracted may be said to have consented to the authority of the state and so incurred an obligation by an act of their own, that is, voluntarily. Hobbes's 'self-assumption' principle would be met. But its merely being the case that one would have consented to the state's authority under certain hypothetical conditions has no such implication. Wolff suggests that Hobbes's hypothetical contract is meant to show (and give the reasons) that we, though perhaps unaware of doing so, in fact $d o$ consent. $5^{6}$ As he notes, though, this cannot provide an account of obligation for all citizens, since some may not accept that the absolute state is better than the state of nature. 57 It is the fact of actual consent that here would provide the basis for obligation (though the consent itself is based on hypothetical reasoning about what one would consent to in other circumstances). It is not the hypothetical consent that the hypothetical covenanters would give to the state that grounds this obligation.

However, interpreting Hobbes's contract as a hypothetical rather than a historical one does not in fact make any difference to his argument for legitimacy, unlike his argument for obligation. This is because, even if Hobbes does not take actual states to be founded on the basis of state-of-nature contracts, he does not need any special argument for their being permitted to enforce their commands. The sort of obligations that could make certain sorts of action between people impermissible only arise once a common power is established over them. States are not subject to any higher sovereign and so, whatever their history, are not in the sort of condition in which any moral requirements apply to them beyond the

\footnotetext{
${ }^{55}$ Dworkin (1973) 501

${ }^{56}$ Wolff (1994) 275-7

${ }^{57}$ Ibid. 275-6
} 
laws of nature. Thus, apart from the constraints imposed by those laws of nature that become binding with the existence of a sovereign, they retain intact their right to all things and so are permitted to enforce their commands not because of any special fact about them, but simply because there are no constraints that apply to them that could make it impermissible.

\section{Conclusion}

I think, then, that Hobbes certainly thinks that states have a general and exclusive permission to enforce compliance with their commands (so long, presumably, as they provide the peace and security that justifies their existence). However, although he could easily be read as giving a voluntarist argument for this permission (and he does seem to be a voluntarist about political obligation), this would in fact be a mistake. Rather, he has no special argument for the permissibility of state enforcement; it simply results from the sovereign not being in the kind of condition in which enforcement could be impermissible. (And the exclusivity of the permission arises simply from the fact that all other members of the society in which the state is sovereign are in a condition where constraints on permissible action are set by the sovereign's laws and commands). Thus, the grounds of state legitimacy in Hobbes's view depend on his scepticism about state-independent morality, that is, on there not being any constraints on morally permissible action except those created by a sovereign power. If we do not share Hobbes's moral scepticism, then, we should not look to his arguments to support state legitimacy. There may of course be Hobbes-inspired arguments for state legitimacy: we could use a Hobbesian argument for the justification of the state as a premise in an argument for legitimacy. But this will need some additional work: we will not find such an argument in Hobbes himself.

\section{References}

Copp, David (1999) 'The Idea of a Legitimate State' Philosophy and Public Affairs 28: 3-45. http://www.jstor.org/stable/2672824

Dworkin, Ronald (1973) ‘The Original Position’ University of Chicago Law Review 40: 500-33. http://www.jstor.org/stable/1599246 
Gauthier, David (1969) The Logic of Leviathan Oxford: Oxford University Press

Green, Leslie (2004) 'Law and Obligations' in Jules L. Coleman, Kenneth Eimar Himma and Scott J. Shapiro (eds.) The Oxford Handbook of Jurisprudence and Philosophy of Law Oxford: Oxford University Press

Hampton, Jean (1986) Hobbes and the Social Contract Tradition Cambridge, UK: Cambridge University Press

Hobbes, Thomas (1996) Leviathan (ed. J.C.A. Gaskin) Oxford: Oxford University Press

Hume, David (1994) Political Essays (ed. Knud Haakonssen) Cambridge, UK: Cambridge University Press

Kavka, Gregory S. (1986) Hobbesian Moral and Political Theory Princeton, NJ: Princeton University Press

Raz, Joseph (1979) The Authority of Law: Essays on Law and Morality Oxford: Oxford University Press

(1988) The Morality of Freedom Oxford: Oxford

University Press

Schmidtz, David (1990) 'Justifying the State' Ethics 101: 89-102. http://www.jstor.org/stable/2381893

Simmons, A. John (2001) Justification and Legitimacy: Essays on Rights and Obligations Cambridge, UK: Cambridge University Press

Sorell, Tom (1991) Hobbes London: Routledge and Kegan Paul

Tuck, Richard (1996) 'Hobbes's moral philosophy' in Tom Sorell (ed.) The Cambridge Companion to Hobbes Cambridge, UK: Cambridge University Press

Wellman, Christopher H. (1996) 'Liberalism, Samaritanism, and Political Legitimacy' Philosophy and Public Affairs 25: 211-37. http://www.jstor.org/stable/2961925 
Wolff, Jonathan (1994) 'Hobbes and the motivations of social contract theory' International Journal of Philosophical Studies 2: 271-86. http://www.tandfonline.com/doi/abs/10.1080/09672559408570795 